\title{
LETTERS TO THE FUTURE
}

An Approacb to Sinyavsky-Tertz 


\section{By the same author}

Sagittarius in Warsaw

Soldier and Tsar in the Forest (translation) 


\section{LETTERS TO THE FUTURE}

An Approach to Sinyavsky-Tertz

RICHARD LOURIE

Cornell University Press

ITHACA AND LONDON 
Copyright (C) 1975 by Cornell University

All rights reserved. Except for brief quotations in a review, this book, or parts thereof, must not be reproduced in any form without permission in writing from the publisher. For information address Cornell University Press, I24 Roberts Place, Ithaca, New York 14850.

First published 1975 by Cornell University Press.

Published in the United Kingdom by Cornell University Press Ltd., 2-4 Brook Street, London WIY IAA.

International Standard Book Number 0-8014-0890-3

Library of Congress Catalog Card Number 74-10413

Printed in the United States of America by Vail-Ballou Press, Inc. 
To my parents 
